\title{
TOYS AND EXPRESSION OF ETHNIC IDENTITY IN SOVIET LITHUANIA. ETHNOGRAPHIC DOLLS AND FIGURINES
}

\author{
Nijolè Pliuraitè Andrejevienè \\ The Open-Air Museum of Lithuania, Rumšiškees, Lithuania \\ e-mail:npliuraite@yahoo.co.uk
}

\begin{abstract}
The article is based on the assumption that ethnographic dolls were a constituent part of the social movement for preservation of the ethnic culture and national identity during the Soviet times. The object of the research is two arrangements of ethnographic dolls titled Wedding in Kupiškis and Mardi Gras Masks. The dolls and their arrangements were created by folk artists Ona Bakanauskienè and Jadvyga Šemetienè in the 1960s-1970s. The goal of the analysis of the ethnographic doll arrangements is to reveal their origins and sources of creation, methods of depiction and their significance for preservation and revival of ethnic culture and national self-awareness.
\end{abstract}

Keywords: ethnic identity, ethnographic dolls, exhibition, Mardi Gras masks, Soviet Lithuania, wedding in Kupiškis 


\section{Introduction}

Dolls are human-shaped figurines that have been used in a wide variety of human activities since times immemorial, such as religious rituals, customs, performances and games of young girls. Dolls that represent the ethnic culture of a nation are called ethnographic dolls. They are custom handmade dolls made of traditional materials and used as figurines (for more information, see Pliuraité-Andrejevienè 2012: 255-274). The differences between dolls and figurines were revealed by Juri Lotman who claimed that figurines and children's dolls relayed information in entirely distinct ways. According to him, a figurine is a mediator between its creator and the audience that it relays information to while children's dolls relay information only during playtime (Lotman 2004: 319). Ethnographic dolls are a form of sculpture and are most often used in exhibitions due to their capacity to relay the information from their maker to the audience.

The making of Lithuanian ethnographic dolls started at the beginning of the $20^{\text {th }}$ century. A team of intellectuals prepared an exhibit of dolls dressed in folk costumes and arranged to represent a scene of matchmaking at a Lithuanian wedding in the countryside. The doll arrangement was presented at an international exhibition in Paris in 1900 (Čerbulenas 1985: 18). State institutions showed their interest in the lack of Lithuanian toys in the 1930s, i.e. during the years of independent Lithuania. According to the cultural historian Lijana Šatavičiūtè, "the focus of national politics was turned to the strengthening of national patriotism, promotion of own culture instead of the Western World, the history of one's family, national heroes, national customs and the beauty of the land's nature" (Šatavičiūtè 2003: 55). Professional artists were the first ethnographic doll makers. Together with her assistant Honorata Ivanauskiené, artist Sofija Užumeckaitė Moisiejevienè made eight Lithuanian dolls for a toy competition in 1931. The dolls represented country folk of different social status dressed in folk costumes (Figure 1). When speaking of the goal of Lithuanian doll making, she said, "I want to use the dolls to show the Lithuanian folk costumes worn in Raseiniai Region in the end of the $19^{\text {th }}$ century as I remember it" (Užumeckaitė Moisiejevienè 1931: 880). This shows that traditional attire worn by country folk were considered as one of the key aspects of national identity in Lithuania during the inter-war period. 


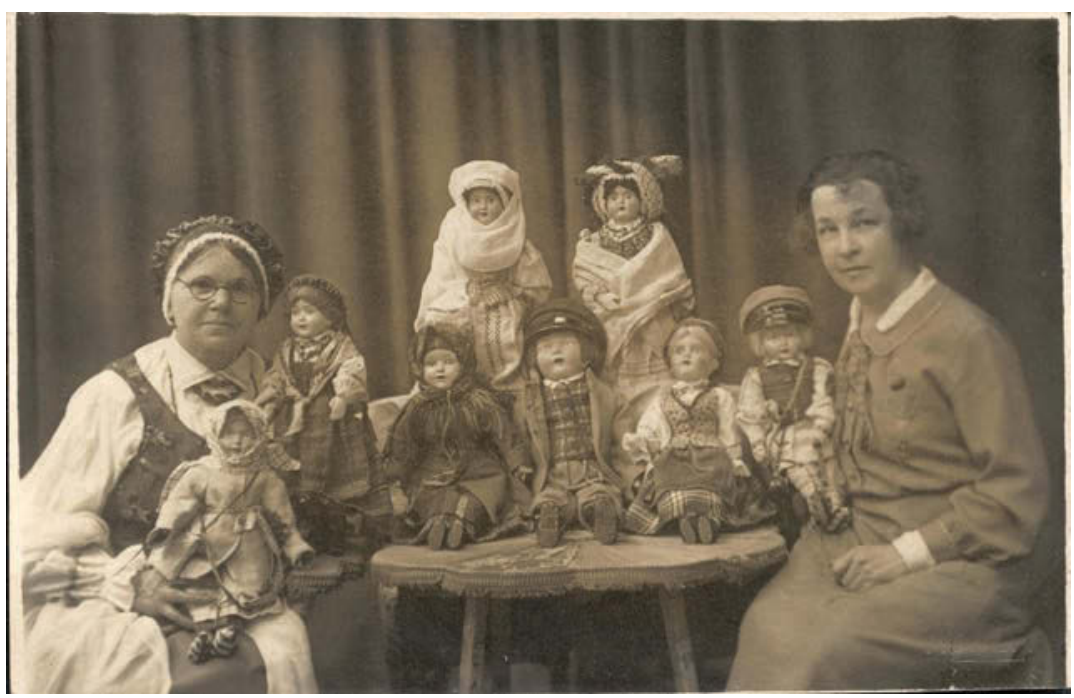

Figure 1. Lithuanian dolls and their makers. S. Užumeckaitè-Moisiejevienè and H. Ivanauskienè. 1931. Kaunas, Lithuania. M. K. Čiurlionis National Museum of Art, Kaunas, Lithuania. Unknown author. ČDM GP 54163/42.

Renowned Lithuanian artists made ethnographic dolls for international exhibitions as per order of the Government. The ethnographic doll arrangement titled Wedding and made by artist Domicelè Tarabildienè was exhibited in Paris in 1937. Artist Konstancija Tulienè created the ethnographic doll arrangement titled Lithuanian Wedding and presented it at the international exhibition in New York in 1939 (Mušinskienè 2008: 1). Both artists focused on the beauty of folk costumes and did their best to reveal their regional differences by displaying the participants of a Lithuanian wedding. The ethnographic dolls created during the inter-war period reflected the Government's aim to revive and preserve the traditional countryside culture.

After Lithuania lost its independence, ethnographic doll makers were faced with new challenges. The Soviet Government deemed Lithuanian folk crafting an important tool in spreading their ideology and encouraged folk artists to choose new topics and to create items reflecting the achievements of socialism or 
dedicated to important events of the Soviet regime (Vaidila 1985: 5-7). However, ethnographic dolls also had a hidden mission of relaying certain information.

The Soviet Government attempted to instil a socialistic culture in Lithuania, at the same time rejecting any ties to the old traditions. In the 1950s, the Government promoted weddings in the style of the Young Communists, where the main roles were played by the friends of the newlyweds rather than their relatives. These weddings had nothing in common with traditions and "quite a few parents felt pushed to the background due to one or another reason" (Daniliauskas 1983: 45-46).

Juozas Mickevičius spoke thus about the approach taken by the Government towards traditional calendar feasts during the Soviet times:

Several students gathered at the home of the student Petronele Sodyte in the evening of the Mardi Gras sometime around 1950. Viržinas, the leader of the youth communist organization in the high school, found out that the students celebrated Mardi Gras by eating pancakes on Shrove Tuesday and reported it to the Principal of the School Jurgis Macelis. The latter made an announcement at the Teacher Council about the participation of the said student in the celebration of Shrove Tuesday. The evaluation of the conduct of $P$. Sodyte was reduced to grade three for making pancakes and refusing to admit her guilt. The other participants had their hair cut short and they had to dance on Saturday evenings during the entire Lent (Mickevičius 2008: 399).

Ideological censorship was applied to limit ethnographic publications on even the most popular traditional calendar customs as long as they were printed. According to Žilvytis Šaknys, such publications were released only from 1957 to 1960 and from 1965 to 1971 in several singled-out cases (Šaknys 2014: 94).

Yet, other possibilities arose to promote traditional ethnographic celebrations. In the 1960s, a social movement dedicated to ethnic culture and local lore grew stronger. Various local lore and folklore clubs and after-school gatherings joined the movement and focused their activities towards gaining a deeper knowledge of the Lithuanian history and ethnic culture to counterbalance the Soviet ideology. The local lore specialists held various expeditions, traditional celebrations, lectures and parties that attracted hundreds and thousands of people. This was a cause for much anxiety to the Government (Ramonaite \& Kukulskytė 2014: 161-181). 
O. Bakanauskienè and J. Šemetienè were self-taught folk artists that arose in the times of this political and cultural turmoil to continue the traditions started by their predecessors, i.e. the Lithuanian doll makers during the inter-war period. These two artists worked hard to make ethnographic dolls that could present certain information to the people that could not be relayed otherwise from the 1950s to the 1980s.

\section{Wedding in Kupiškis}

O. Bakanauskienè was born in a family of Lithuanian emigrants in Dnipropetrovsk City (Russia) in 1915. She decided to return to Lithuania in 1936 and stayed in Kaunas. O. Bakanauskiene had various jobs, worked as an actor in the Kaunas Young Spectator's Theatre and was an active participant in cultural activities held in Kaunas. Without a doubt, she was familiar with the ethnographic dolls created by K. Tuliene for the New York exhibition as they were widely promoted in the inter-war press. Perhaps this influenced the artist's future choice to make similar doll arrangements. O. Bakanauskiene lost both her husband and son after the war. She led a difficult life and soon turned to doll making as a source of livelihood. The employees of Kaunas Museum noticed her dolls accidentally and suggested that she made more dolls like these and took part in the first folk art exhibition to be held after the war in Kaunas in 1952 (Ramanauskiene 1958: 41). Since 1953, O. Bakanauskienè had been an active member of all associations uniting folk artists and artisans. She worked from home for Kaunas Daile Art and Craft Factory and dedicated her free time for making doll arrangements. During the Soviet times, the dolls made by O. Bakanauskiene were displayed at folk art exhibitions in the categories of folk textile and souvenirs. The exhibitions were held in Lithuania and other Republics of the Soviet Union, Poland and Czechoslovakia.

In 1970, O. Bakanauskiene created a doll arrangement portraying the characters of the ethnographic performance titled Wedding in Kupiškis and reflecting the old wedding customs at the home of the bride's parents. The history of the performance dated back to 1932, when it was first held in Kupiškis County in the Highlands (Lith. Aukštaitija Region). Several enthusiasts came together and prepared an ethnographic performance titled Wedding in Kupiškis. The participants of the performance wrote the plot about wedding customs in Kupiškis County back at the end of the $19^{\text {th }}$ century and the beginning of the 
$20^{\text {th }}$ century based on their own memories and narrations by other people. The ethnographic performance quickly became popular in Kupiškis County and other regions of Lithuania as well (Zabielienè 2004: 30).

The residents of Kupiškis County remembered the first ethnographic performance vividly even during the Soviet times after the war. These memories were the stimulus that encouraged the intelligentsia of Kupiškis Town to gather country folk and revive this ethnographic performance once again. Aušra Zabieliene noticed that the wedding customs depicted in the play were the same as the customs of Kupiškis residents described in various ethnographic sources. The said ethnographic material was collected and published in a cultural magazine by a renowned photographer, museum attendant and local lore specialist Balys Buračas in 1935 (Zabielienè 2004: 31). The second era of the Wedding in Kupiškis ethnographic performance started in 1966. O. Bakanauskienè saw the performance several years later, in 1969. According to her daughter Laimute Levickienè, born in 1941, O. Bakanauskienè was so impressed by the Wedding in Kupiškis performance that she felt the drive to make dolls representing the characters of the play and reflecting the old wedding customs (e.g. L. Levickiene, fieldwork data of 06.03.2017).

O. Bakanauskienè made a doll arrangement comprised of 32 dolls in half a year. The doll arrangement had all the main characters of the wedding play: the matchmaker, the challenger of the wedding giving out invitations, bridesmaids, groomsmen, the bride and her parents, brother and sister, the groom, musicians, the judge of the matchmaker, the guests of the wedding, the wedding hostess and host and carriers of the dowry chest. The $20-30 \mathrm{~cm}$ tall dolls were handmade from wires and cardboard and their heads and hands were made of wood using the craft of woodturning. The wooden parts of the dolls were made by folk artist Petras Levickas who was the son-in-law of O. Bakanauskiene. The facial expressions were cut out from coloured paper, cardboard or artificial leather while the hair of the dolls was made from flax.

The dolls wore traditional male and female attire, shoes and even sashes which were a time-honoured dress element of the country folk in the Highlands. The doll clothes were made of handmade woven fabrics purchased from weavers and folk artists or at folk art and craft store. O. Bakanauskienè also made doll clothes, sample shoes and embroidered decorations herself based on the samples of folk costumes prevalent in the Highlands and collected by artist Antanas Tamošaitis (Tamošaitis 1939: 39-43). She also made other wedding attributes 


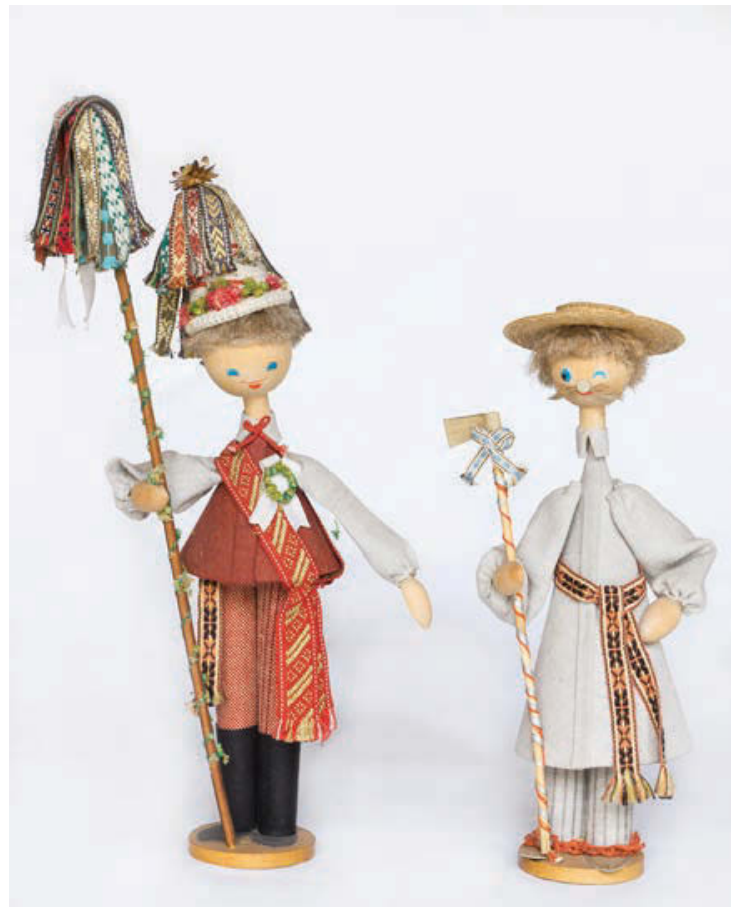

Figure 2. Characters of a wedding in Kupiškis. The wedding challenger and the matchmaker. Šiauliai Aušra Museum. Šiauliai, Lithuania. Photo by Rimgaudas Žaltauskas 2017. ŠAM 5406/7-8.

and elements used in the ethnographic performance, e.g. O. Bakanauskiene learned how to make the himmeli-type straw decoration called the Orchard by taking apart a similar ornament made by another artisan.

All the wedding characters were placed either alone or in small groups on a plinth like statuettes. The dolls seemed like characters on a stage and so the doll arrangement gave the impression of a performance. The matchmaker stood with a staff in hand depicting the moment the matchmaker and the groom arrived to greet the bride on the morning of the wedding (Figure 2). The challenger of the wedding also had a staff and wore a hat adorned in colourful ribbons. 


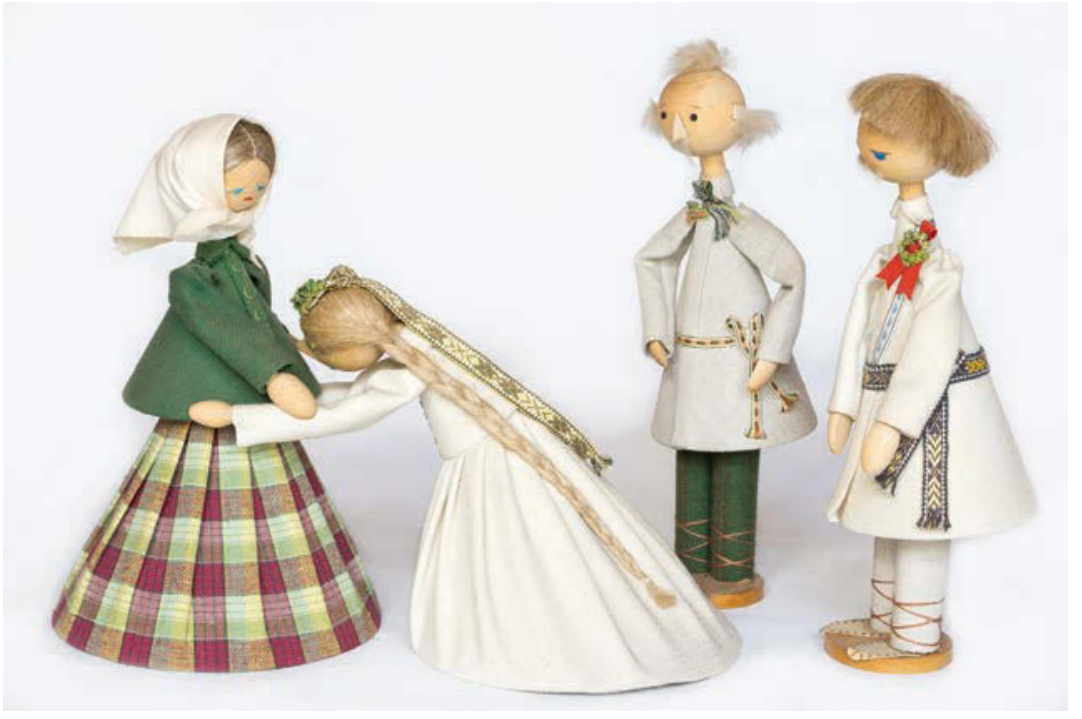

Figure 3. Group doll arrangement. The bride's farewell to her parents. Šiauliai Aušra Museum. Šiauliai, Lithuania. Photo by Rimgaudas Žaltauskas 2017. ŠAM 5406/1-4.

This was the scene, where the challenger of the wedding was inviting all the neighbours to escort the bride to the church. The grouped dolls depicted the bride's entourage, i.e. the bridesmaids and groomsmen, who accompanied the bride to the church. The bridesmaid dolls were dressed in folk costumes and wore traditional fabric wreaths called Kalpokas. The wreaths were a traditional bridesmaid headdress adorned in artificial flowers and worn in Kupiškis County until the beginning of the $20^{\text {th }}$ century. The groomsman dolls were dressed in white linen attire strapped with a folk sash and all of them had the symbol of a groomsman, i.e. a pocket square with a branch of rue. The grouped doll arrangement of the bride, her parents and the groom reflected the scene of the bride saying goodbye to her parents before leaving for the church (Figure 3). The wedding celebration was even more realistic with several dolls depicting musicians with traditional musical instruments escorting the bride to the church. The custom of hanging the matchmaker during the wedding in the Highlands was reflected by a doll depicting a judge reading the verdict to the 
lying matchmaker. Dolls wearing headdresses depicted guests of the wedding as these types of headdresses were worn by married women in the Highlands until the end of the $19^{\text {th }}$ century. The guests of the wedding held a traditional straw decoration called the Orchard (also known as himmeli) in their hands as it reflected the wedding custom of buying the orchard to gain the right to feast at the table. The doll arrangement also had characters depicting the wedding host with a pitcher of beer and the wedding hostess with a cake. The last dolls of the arrangement were the carriers of the dowry chest. They wore large straw hats and had sashes and straw swords. A small dowry chest was placed nearby. The wedding rituals at the bride's home ended with the dowry chest being taken to the groom's house.

The Wedding in Kupiškis doll arrangement made by O. Bakanauskienė was displayed in the folk art exhibitions in Vilnius and Moscow in 1970. An article discussing the Moscow exhibition called the dolls of the Wedding in Kupiškis made by $\mathrm{O}$. Bakanauskiene a popular souvenir, the creation of which required proficient knowledge of sculpture, deep understanding of folk costume designs and subtle taste (Počiulpaitė 1981:5). O. Bakanauskienė was awarded a number of certificates of acknowledgement, diplomas and meritorious awards given "for ingenuity in creative work" (Blužienè 1970: 1). A set of greeting cards with photos of the Wedding in Kupiškis doll arrangement was released in 1971. The set introduction described the ethnographic wedding dolls as "a piece of our nation's history" (Bakanauskienè 1971:11).

To be able to make ethnographic dolls, O. Bakanauskienè had to adapt to the policy of the Government and to take part in exhibitions dedicated to the commemoration of significant events to the history of the Soviet Union. O. Bakanauskienè had favourable conditions to freely make ethnographic dolls during the Soviet times because she was a member of the Folk Art and Craft Union which supervised folk artists and their work.

The dolls of the Wedding in Kupiškis doll arrangement contributed to the reconstruction, revival and preservation of the old wedding customs. 


\section{Mardi Gras Masks}

Not much is known about the life of J. Šemetiené, born in 1923. She lived in Kaunas during the Soviet times and worked as a teacher of crafts in a school. The artist started making ethnographic doll arrangements in the 1970s. She offered the Open-Air Museum of Lithuania to acquire her very first doll arrangement titled Mardi Gras Masks in 1980. She said that she taught children how to make dolls during her crafting classes and sometimes made parts of figurines together with her young students. J. Šemetiene called herself a master folk artist but she did not participate in any folk art exhibitions and was not a member of any folk art and craft unions. Being highly skilled in arts and crafts, J. Šemetiene made dolls in her free time for her own pleasure (e.g. J. Šemetiene, fieldwork data of 06.03.1980). J. Šemetienè must have visited folk art exhibitions as she lived in Kaunas and must have seen the ethnographic doll arrangements made by O. Bakanauskiene. These exhibitions might have encouraged J. Šemetiene to start making dolls like these as her methods of doll making and depiction were quite similar to those of O. Bakanauskiene. This is why J. Šemetienè can be considered a follower of the creative works of O. Bakanauskienè.

Mardi Gras is a winter festival celebrated on the last day before the Lent which lasts for a month and a half. Even though this celebration had no direct connection to religion, its relation to the religious calendar was enough of a reason for the Soviet Government to try to eradicate the Mardi Gras traditions (Kudirka 1996: 4). Besides denying and banning the old religious festivals during the first years of the Soviet occupation, an attempt was made to create socialist festivals with nothing in common with the traditional ones. As this idea failed, the authorities decided to take advantage of the old festivals by giving them a 'socialist content'. Merriment was encouraged during the Lenten period in another manner, i.e., by holding a winter festival, which replaced Mardi Gras (Šaknys 2015: 114). Mardi Gras was called the Winter Banishment Festival during the Soviet times. Its revival started in the 1950s. According to Lina Petrošienè who researched the development of this festival during the Soviet times, the celebration was brimming with contradictions and was very diverse in nature (Petrošienè 2014: 48). Even though some people kept trying to hold a traditional Mardi Gras celebration, their "spontaneous communityinspired initiatives were suppressed and heavily controlled" (Petrošiene 2014: 55). The festival agenda was often unified or undergoing constant changes as 


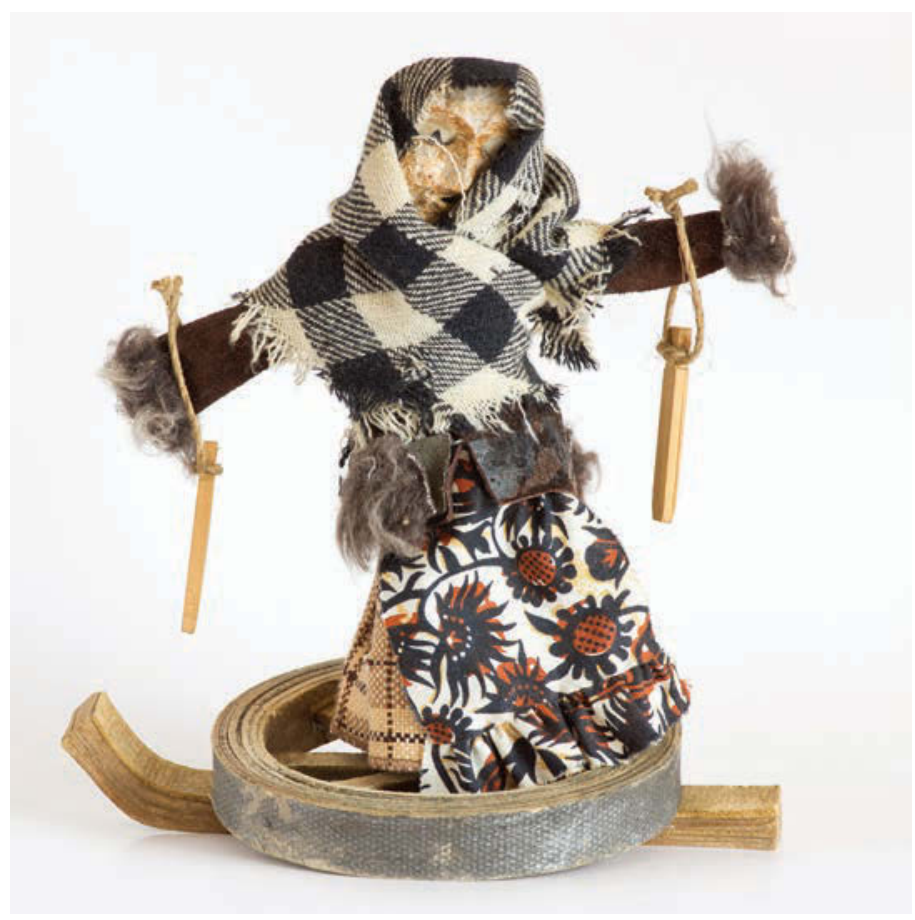

Figure 4. Mardi Gras character Morè. Open-Air Museum of Lithuania, Rumšrškès, Lithuania. Photo by Rimgaudas Žaltauskas LBM 27467.

several of its holders from cultural institutions tried to vary or incorporate the old Mardi Gras customs into the enforced new ones. It was thanks to the researchers of ethnic culture and certain separate individuals that "significant attempts to resist and at least partially preserve our national identity were made during this complex historical period" (Petrošienè 2014: 48).

When speaking of her inspiration, J. Šemetiene said that she was most impressed with the photos and slides of traditional Mardi Gras festival characters and masks worn by the participants of the Mardi Gras celebrations. She also saw samples of traditional wooden masks in folk art exhibitions (e.g. J. Šemetiené, fieldwork data of 29.07.1980). 
J. Šemetienè made a doll arrangement consisting of twenty dolls that depicted the main characters of the Mardi Gras festival, their masks and other inventory. The dolls were either solitary or grouped into couples and placed on a plinth much like statuettes. The doll arrangement looked like a march of Mardi Gras characters intent on joking around, having fun and entertaining others.

J. Šemetienè assembled the bodies of handmade dolls from wooden and plastic sticks and covered them in cotton wool. Masks or plastic balls with masks served as the heads of the dolls. The legs were wooden and the dolls had either leather shoes or natural felt boots.

All Mardi Gras dolls had masks and wore traditional folk costumes of country folk. These elements were a reflection and an impression of the typical looks of the respective characters, their personality features and mood. The costumes of the dolls were sewn from handmade woven or factory-made fabrics by J. Šemetienè herself.

J. Šemetienè created the Mardi Gras masks using the papier-mâché method by mixing paper and adhesive and gluing the paper strips to the clay mask mold made by herself. When the mask hardened and got dry, J. Šemetienè would colour it and place it on the doll's head.

The doll arrangement by J. Šemetiene depicted traditional characters of Mardi Gras, e.g. the More character impersonated by a doll dressed in a peasant's clothing and fixed on a wheel or the runners of a sled (Figure 4). The oldest traditional masks were those of a goat and a bear and were also portrayed in the Mardi Gras doll arrangement, where these characters were depicted as playing the drums or double-bass. This highlighted the revel typical to Mardi Gras celebrations that were full of music and songs. The Mardi Gras doll arrangement also displayed traditional masks that made fun of people of other nationalities, such as the Jews or gipsies, due to their distinct traditions and lifestyles. The dolls also drew parallels between the Mardi Gras characters and Christianity by portraying the devil, the Reaper and the witch. J. Šemetiene liked to bring different Mardi Gras characters together, e.g. making a couple of the devil and the witch to reveal the sentiments of mischief and tricks typical to Mardi Gras (for more information on Lithuanian Mardi Gras characters, Vaicekauskas 1995). Other dolls represented characters that reflected the common country folk, such as Newlyweds, A Pair of Paupers, The Rider. The coupled devil and spinster characters revealed the negative attitudes of the country folk towards unmarried women during the Mardi Gras (Figure 5). 


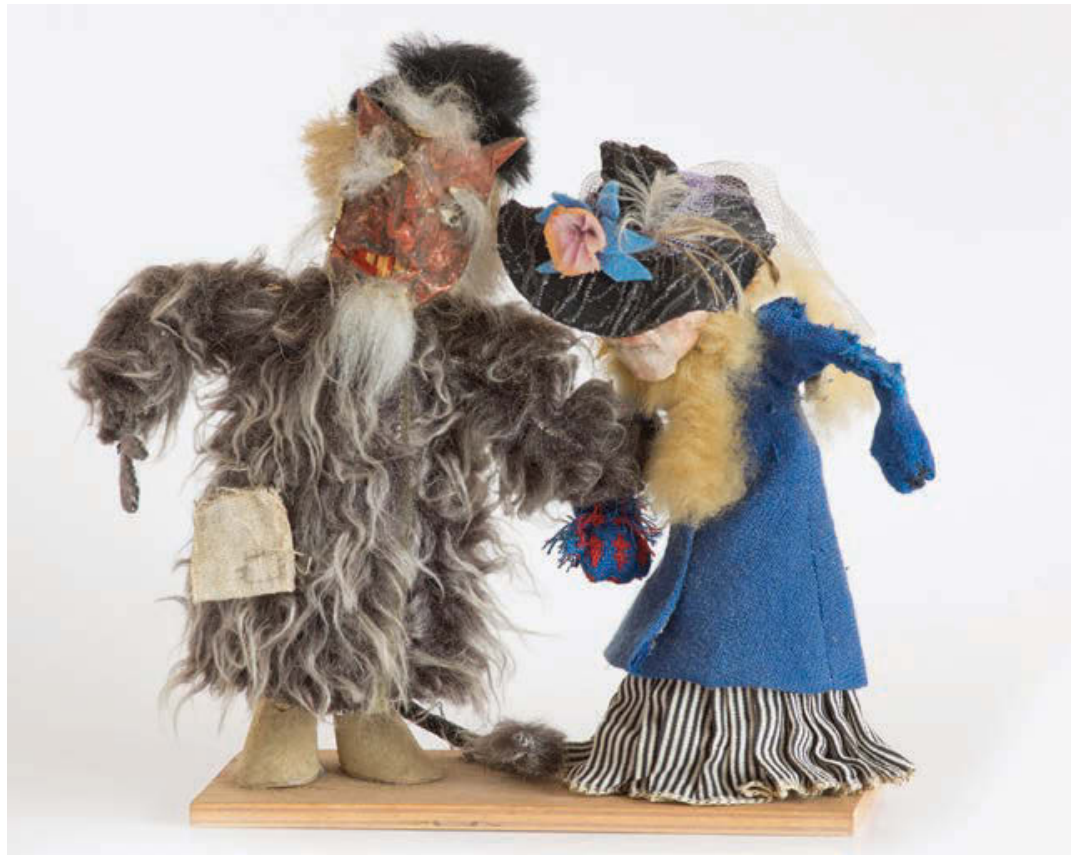

Figure 5. Mardi Gras characters. The devil and the spinster. Open-Air Museum of Lithuania, Rumšiškès, Lithuania. Photo by Rimgaudas Žaltauskas. LBM 27470.

This way, J. Šemetiene used the language of dolls to portray traditional Mardi Gras characters instead of the socialist players of the Winter Banishment Festival, such as bribetakers, illegal traders, bureaucrats or moonshiners (cf. Černeckis 1961: 9).

\section{Conclusions}

The research revealed that Lithuanian dolls made by professional artists with the goal to represent their ethnic culture in various exhibitions were the predecessors of ethnographic dolls made during the Soviet times. The traditions of Lithuanian doll making were continued during the Soviet times by folk artists 
O. Bakanauskienė and J. Šemetienė who based their work on ethnographic and folklore events held at that time and other visual materials. These artists made theatricalised ethnographic doll arrangements to reconstruct the old customs of rural weddings and Mardi Gras and the participants of these celebrations and their attributes, hence helping to preserve and revive these customs. This was how ethnographic dolls evolved from being used as tools of ideological education by the Soviet Government into important messengers of cultural information that was not tolerated by the Soviet regime. The article confirmed the assumption that ethnographic doll making was closely related to the nurturing of national values and was a constituent part of the social movement that fought to preserve ethnic culture and national identity.

\section{References}

Bakanauskienè, Ona 1971. Kupiškènu vestuvès [Wedding in Kupiškis]. 11 atviruku komplektas. Vilnius: Mintis.

Blužienè, Teresė 1970. Liaudies menininkès Onos Bakanauskienès kürybinių darbų paroda [Exhibition of Creative Works of Folk Artist Ona Bakanauskienè]. Vilnius: Liaudies meno draugija.

Čerbulènas, Klemensas 1985. Lietuvių tautodailè užsienio parodose [Lithuanian Folk Art in Foreign Exhibitions]. In: A.Vaidila (ed.) Liaudies dailes parodos ir komunistinio auklejjimo uždaviniai [Folk Art Exhibitions and Objectives of Communist Education]. Vilnius: Lietuvos TSR mokslinis metodinis kultūros centras, Lietuvos TSR liaudies meno draugija, pp. 18-21.

Černeckis, Vincas 1961. Naujo gyvenimo tradicijos [Traditions of a New Life]. Vilnius: Valstybinè politinès ir mokslinès literatūros leidykla.

Daniliauskas, Antanas 1983. Etninès darbininkų kultūrinio gyvenimo problemos [Spiritual Culture of the Lithuanian Industrial Workers]. In: A. Daniliauskas \& P. Kalnius, Lietuvos TSR pramonès darbininku kultūros ir šeimos etnografinès problemos [Ethnographic Problems in Relation to the Culture and Families of Industrial Workers in the Lithuanian SSR]. Vilnius: Mokslas, pp. 4-66.

Kudirka, Juozas 1992. Užgavenės [Shrove Tuesday]. Vilnius: Mokslas.

Lotman, Juri 2004. Lèlès kultūros sistemoje [Dolls in the Cultural System]. In: A. Sverdiolas (ed.) Kultūros semiotika / Semiotics of Culture. Vilnius: Baltos lankos, pp. 319-324. 
Mickevičius, Juozas 2008. Tëvų ir protèviu žemé: I knyga [The Land of Parents and Grandparents: The $1^{\text {st }}$ Book]. Vilnius: Regionų kultūrinių iniciatyvų centras.

Mušinskiene, Julija 2008. Collection of Dolls Returned to Lithuania from the US. Available at http://www.bernardinai.lt/straipsnis/2008-07-30-julija-musinskiene-isjav-i-lietuva-sugrazinta-leliu-kolekcija/9521, last accessed on 26.03. 2018.

Petrošienè, Lina 2014. Užgavėnès arba Žiemos palydų šventè sovietmečiu. [Lithuanian Shrovetide or the Ushering-out-of-Winter Festival in the Soviet Period]. Istorija. Mokslo darbai, Vol. 93, pp. 48-68. Vilnius: Lietuvos edukologijos universitetas.

Pliuraitè-Andrejevienè, Nijolè 2015. Lietuvos vaikų žaislai [Lithuanian Children's Toys]. Vilnius: Versus Aureus.

Počiulpaité, Alè 1981 = Pochyulpayte, Ale 1981. Vystavka rabot narodnykh masterov Litvy [Exhibition of Works by Lithuanian Folk Artists]. Vilnius: Obshchestvo narodnogo iskusstva Litovskoy SSR, pp. 1-5.

Ramanauskienè, Petrutè 1958. Ir lèlès gali gyventi [Dolls Too Can Live]. Meno saviveikla, No. 5 , p. 41.

Ramonaitè, Ainè \& Kukulskytė, Rytė 2014. Etnokultūrinis judejjimas sovietmečiu: nematoma alternatyva sistemai? [The Ethno-Cultural Movement in the Soviet Lithuania: The Invisible Alternative to the Regime?] Lietuvos etnologija: socialines antropologijos ir etnologijos studijos, Vol. 14 (23), pp. 161-181.

Šaknys, Žilvytis 2014. Tradicinių kalendorinių papročių tyrimai sovietinèje Lietuvoje [The Research of Traditional Calendar Customs in Soviet Lithuania]. Etnografija 2010, No. 20, pp. 92-105.

Šaknys, Žilvytis 2015. Užgavėnès: a Rural and Urban, Religious, Socialist and Lithuanian Festival of Shrovetide. Folklore: Electronic Journal of Folklore, Vol. 60, pp. 105-128.

Šatavičiūtè, Lijana 2003. Tautinès keistenybès tarpukario Lietuvoje [National Peculiarities in Interwar Lithuania]. Menotyra, No. 2 (31), pp. 55-60.

Tamošaitis, Antanas 1939. Lietuvių moterų tautiniai drabužiai [Folk Costumes of Lithuanian Women]. Sodžiaus menas, Vol. 7-8, pp. 5-207.

Užumeckaitè-Moisiejevienè, Sofija 1931. Lietuviškos lèlès [Lithuanian Dolls]. Romuva, No. 37, p. 880.

Vaicekauskas, Arūnas 2005. Lietuvių žiemos šventės: Bendruomeninės kalendorinio ciklo apeigos XIX a. pab. - XX a. pr. [Lithuanian Winter Festivals: The Rites of the Community Calendar Cycle in the Late $19^{\text {th }}-$ Early $20^{\text {th }}$ Centuries]. Kaunas: VDU leidykla. 
Nijolè Pliuraitė Andrejevienè

Vaidila, Albertas 1985. Liaudies dailès parodų ideologinio veiksmingumo problemos [Problems of Ideological Effectiveness of Folk Art Exhibitions]. In: A. Vaidila (ed.) Liaudies dailes parodos ir komunistinio auklejimo uždaviniai [Folk Art Exhibitions and Objectives of Communist Education]. Vilnius: Lietuvos TRS mokslinis metodinis kultūros centras, pp. 5-7.

Zabielienè, Aušra 2004. Trejos kupiškènu vestuvès [Three Weddings in Kupiškis]. Liaudies kultūra, No. 1, pp. 29-33. 